Інститут інформаційних технологій засобів навчання НАПН Украӥни

\title{
СУЧАСНI ТЕХНІЧНІ ЗАСОБИ НАВЧАННЯ ЯК СКЛАДНИК НОВІТНІХ ІНФОРМАЦІЙНИХ ТЕХНОЛОГІЙ
}

\begin{abstract}
У статті на основі порівняння та зіставлення різних шляхів реалізації курсу «Технічні засоби навчання» запропоновано новий підхід до викладання курсу студентам педагогічних спеціальностей. Автори пропонують поділити курс на два складники: апаратні засоби навчання та програмні засоби навчання.

Ключові слова: технічні засоби навчання (ТЗН), мультимедійні засоби навчання (МЗН), інформаційні технології, цифрові пристрої, програмне забезпечення.

В статье на основе сравнения и сопоставления различных путей реализации курса «Технические средства обучения» предложен новый подход преподавания курса студентам педагогических спеииальностей. Авторы предлагают разделить курс на две составляющие: аппаратные средства обучения и програмные средства обучения.

Ключевые слова: технические средства обучения (ТСО), мультимедийные средства обучения (МЗО), информационные технологии, цифровые устройства, программное обеспечение.
\end{abstract}

This article, based on comparing and contrasting the different ways to implement the course «Technical means learning» a new approach of teaching the course for students teaching specialties. The author proposes to divide the course into two parts: hardware and software tools training.

Key words: technical training (TT), multimedia learning tools (MLO), information technology, digital devices, software.

Збільшення інформаційного потоку значною мірою впливає на якість підготовки фахівців, що залежить від інтенсифікації та оптимізації навчального процесу на основі ефективного використання класичних та активного впровадження нових методик, що грунтується на використанні різноманітних технічних засобів навчання (ТЗН). Науково-технічний прогрес і сучасна наука, забезпечуючи педагога найновішими технічними засобами викладання навчального матеріалу, вимагають від нього постійної самоосвіти та зусиль щодо вдосконалення педагогічної майстерності та методики використання інноваційних ТЗН як однієї 3 найвагоміших умов забезпечення належного рівня підготовки фахівців.

Meта статmi - дослідити та проаналізувати сучасний стан викладання курсу «Технічні засоби навчання» й запропонувати авторську методику.

Перебудова загальноосвітньої середньої школи вимагає не тільки перегляду і вдосконалення змісту загальної освіти відповідно до нових завдань сучасного суспільства, але й активізації методів організації навчального процесу. Важливого значення з огляду на це набуває питання використання в педагогічному процесі мультимедійних засобів навчання (МЗН), які є невід’ємною частиною інноваційних ТЗН. Під МЗН розуміємо сукупність різних засобів навчання, як-от: текстів, графічних зображень, музики та відео, спрямованих на здобуття знань, удосконалення вмінь та навичок учнів.

МЗН забезпечують різні види діяльності, що грунтуються на комплексному використанні різних типів інформаційних процесів у межах єдиного технічного комплексу. При використанні новітніх комп’ютерних технологій з'явилася можливість збільшення обсягу візуальної інформації, що сприяє прискоренню засвоювання будь-якої інформації (як під час вивчення технічних дисциплін, так і під час засвоєння гуманітарних предметів). Збільшується можливість унаочнити викладання не тільки теоретичного матеріалу, призначеного для вивчення, але й покроково відобразити хід практичної роботи, супроводити повідомлення чи доповідь відеорядом. Для отримання освіти з використанням комп’ютерних технологій необхідні три основні складові: апаратно-програмні засоби, кваліфікований викладач та електронні навчальні матеріали.

У результаті проведеного аналізу сучасних досліджень і публікацій іноземних та вітчизняних науковців із проблеми застосування сучасних ТЗН з'ясовано, що це питання було відображено у роботах таких відомих учених, як: M. Allan, J. Baurmann, P. Berlinhof, E. Dale, H. Finger, J. Higgins, J. Loregran, M. Löschmann, В. Алаликін, С. Архангельський, Л. Банкевич, Б. Бенедиктов, I. Берман, В. Беспалько, В. Биков, Н. Бичкова, Е Бондаренко, А. Братко, І. Булах, В. Васильєв, С. Величко, В. Волинський, Н. Головкіна, С. Гончаренко, П. Гороль, Т. Григор'єва, Р. Гуревич, А. Гуржій, Ю. Жук, Л. Зайцева, А. Карецький, Т. Коваль, Г. Коджаспірова, С. Коршак, І. Кошман, О. Крюкова, А. Лур'є, В. Ляудис, М. Ляховицький, О. Ляшенко, Б. Миргородський, О. Михайлова, Е. Носенко, I. Павлова, I. Панова-Яблошникова, К. Петрова, В. Поляков, Л. Пресман, В. Прокоф'єва, П. Сердюков, Н. Скляренко, О. Смирнова, Л. Соловйова, А. Хуторський, Л. Цесарський, М. Шут та iн. 
Задля визначення, оптимальних шляхів вивчення курсу «Технічні засоби навчання», ми ознайомилися з різними тлумаченнями терміна ТЗН.

На думку Г. Коджаспірової, «технічні засоби навчання - це сукупність технічних пристроїв 3 дидактичним забезпеченням, які використовуються в навчально-виховному процесі для викладання та оброблення інформації 3 метою його оптимізації» [5, с. 24]. Таким чином, термін технічні засоби навчання об'єднує два поняття: технічні пристрої (апаратура) та дидактичні засоби навчання (носії інформації), які відтворюються за допомогою цих пристроїв. В англомовних джерелах ТЗН називають аудіовізуальними засобами, які, у свою чергу поділяються на апаратну (hardware) та програмну частини комп'ютерного забеспечення (software). У тлумаченні П. Гороля, ТЗН це «система засобів, яка складається 3 двох взаємопов'язаних частин: перша - специфічні навчальні посібники, або носії аудіовізуальної інформації, друга - це апаратура, за допомогою якої подається інформація» [3, с. 7$]$.

Сьогодні чітко визначилися три головні напрямки використання комп'ютерів як ТЗН у навчальному процесі.

По-перше, це навчання технологій, що вимагають активного використання комп'ютера (графічні і текстовий редактори, електронні таблиці, бази даних, робота у комп'ютерних мережах); навчання спеціалізованих технологій (створення музики, комп'ютерне конструювання й анімація, макетування, верстка тощо)

По-друге, вивчення інформатики як науки, що розглядає інформаційно логічні моделі.

По-третє, використання комп’ютера як технічного засобу у вивченні основ наук у школі та ПТНЗ, фундаментальних і технічних дисциплін у вищих навчальних закладах [3, с. 221].

Метою дослідження $\epsilon$ відображення процесу формування знань, умінь і навичок у студентів, необхідних для застосування сучасних технічних засобів у навчально-виховному процесі; розвиток пізнавальних та творчих інтересів майбутніх педагогів, їх готовності до самостійної праці та пошуку шляхів підвищення продуктивності педагогічної праці.

Результати аналізу робочих програм, методичного забезпечення та різних інформаційних джерел 3 курсів спрямованих на вивчення технічних засобів навчання, показали, що: 1) технічне забезпечення в навчальних закладах освіти не відповідає сучасним європейським стандартам щодо оснащення лабораторій ТЗН; 2) більшість літературних джерел нині відображає застаріле обладнання не в історичному огляді, а як сучасний стан проблеми; 3) відсутні віртуальні лабораторні комплекси, які б імітували виробничий процес у реальних умовах праці; 4) необхідна підготовка й перепідготовка викладачів професійно-технічних навчальних закладів до використання сучасних ТЗН при викладанні загальноосвітніх та спеціальних дисциплін; 5) є необхідність проведення провідними виробниками інформаційно-комунікаційних технологій підвищення кваліфікації педагогів; 6) презентацій сучасних та експериментальних навчальних ТЗН; 7) щорічних тренінгів 3 їх використання; 8) проведення конкурсів з підготовки методичного забезпечення по їх використанню; 9) неможливо в сучасних умовах навчання за відсутності необхідних ТЗН підготувати майбутнього педагога професійного навчання до використання їх у майбутній професійній діяльності; 10) необхідно вдосконалити методику використання сучасних ТЗН.

Ураховуючи вищесказане, акцентуємо на необхідності оновлення змісту навчального матеріалу при підготовці курсу «Технічні засоби навчання» для студентів спеціальності «Професійне навчання (за профілем)».

Запропоновану нами робочу програму укладено відповідно до вимог Болонського процесу за модульною системою та поділено на два змістових модулі. Послідовність цих модулів відповідає логічному викладанню матеріалу.

Перший модуль, який має назву - «Сучасні апаратні комп’ютерні засоби навчання», складається 3 таких тем:

1. Вступ. Людські можливості щодо сприйняття інформації. Місце і роль ТЗН в пізнавальному процесі (ці теми запропоновано на самостійне опрацювання, де джерелом вивчення $є$ розроблені нами методичні рекомендації).

2. Сучасні апаратні комп’ютерні засоби навчання, їх класифікація та можливості використання, а саме: вивчення архітектури сучасного комп'ютера: процесор, пам'ять, відеокарта, звукова карта, порти; вивчення периферійних пристроїв: монітори, клавіатури, маніпулятори «миша», принтери, сканери, графічні планшети, використання аудіопристроїв: мікрофонів, колонок, навушників; використання відеопристроїв: цифрових фотоапаратів, відеокамер, веб-камер; застосування мультимедійних проекторів у навчальному процесі; застосування мультимедійних (інтерактивних) дошок в навчальному процесі. Ця тема вивчається на лабораторному практикумі з використанням сучасних інформаційно-комунікаційних технологій та сучасної методики їх використання, що представлено в методичних вказівках до виконання лабораторних робіт. Кожна лабораторна робота включає теоретичний матеріал, який відповідає сучасному комп’ютерному обладнанню; практичну частину, яка містить хід роботи з ТЗН: порядок його ведення в експлуатацію, налаштування параметрів оптимальної роботи апаратної частини, робота 3 програмним забезпеченням; передбачає відповіді на контрольна запитання 
Другий модуль, який має назву - «Сучасні програмні комп’ютерні засоби навчання», включає в себе: методико-дидактичні аспекти застосування сучасних програмних комп'ютерних засобів навчання (текстові процесори та їх використання при підготовці дидактичних матеріалів, використання об'єкта для створення формул, створення організаційних діаграм, створення блок-схем, детальне вивчення програмних засобів для створення презентацій, вивчення методів демонстрації презентацій, практичне використання програмних засобів створення сайтів, практичне використання програмних засобів створення публікацій, практичне використання програмних засобів для проведення конференцій, вивчення програмних середовищ для створення навчально-контролюючих програм, методика створення тестів, вивчення програмних засобів дистанційного навчання, створення дистанційних курсів тощо). До лабораторного практикуму 3 цієї теми включено індивідуальні творчі завдання, які передбачають підготовку та проведення нетрадиційного заняття 3 використанням сучасних апаратних та програмних комп'ютерних засобів навчання.

У результаті вивчення курсу студенти повинні знати об'єктивність застосування сучасних ТЗН, місце та роль сучасних ТЗН у навчально-виховному процесі, сучасні технічні засоби навчання, їх основні характеристики та методику їх застосування та вміти: обирати відповідні технічні засоби залежно від напряму педагогічних дій, користуватись обраним технічним засобом, завантажувати відповідне програмне забезпечення та використовувати його на заняттях.

Отже, запропонований курс має динамічних характер і має щорічно оновлювати зміст викладеного матеріалу, відповідно до розвитку та впровадження сучасних навчальних IКТ в освітній процес, що $\epsilon$ обов'язковою умовою європейських навчальних закладів та запорукою підготовки кваліфікованих, мобільних та інформаційно освічених фахівців.

\section{Література}

1. Бондаренко Е. А. Технические средств обучения в современней школе : пособие для учителя и директора школы / Е. А. Бондарено, А. А. Журим, И. А. Милютина; под ред. А. А. Журина. - М. : ЮНВЕС, 2004. - 104 с. 2. Беспалько В. П. Образование и обучение с участием компьютеров (педагогика третьего тысячелетия) / В. П. Беспалько. - М. - Воронеж : МПСИ; МОДЕК, 2002, 348 с. 3. Гороль П. К. Сучасні інформаційні засоби навчання: [навч. посіб.]. - К. : Освіта України, 2007. - 536 с. 4. Гороль П. К. Методика використання технічних засобів навчання: [навч. посіб. для студ. вищ. пед. навч. закл.] / П. К. Гороль - К. : Освіта України, 2007. - 256 с. 5. Коджаспирова Г. М. Технические средства обучения и методика их использования: [учебн. пособ. для студ. высших завед.] / Г. М. Коджаспирова, К. В. Петров. - М. : Академия, 2001. 6. Мультимедиа в образовании: контекст информатизации. - М. : Издательский сервис, 2004. - 320 с. 